\title{
HUBUNGAN LAMA KERJA DENGAN KELUHAN GANGGUAN PERNAPASAN PADA PUMULUNG DI TPA SEI GILING KOTA TEBING TINGGI
}

\author{
Delita Br Panjaitan ${ }^{1}$, Taufik Ashar ${ }^{2}$ dan Nurmaini ${ }^{3}$ \\ Progaran Studi Kesehatan Masyarakat Fakultas Kesehatan Masyarakat \\ Institut Kesehatan Medistra Lubuk Pakam \\ Jl. Sudirman No.38 Lubuk Pakam Kec. Lubuk Pakam Kab. Deli Serdang, \\ Sumatera Utara \\ Email: delita.lita16@gmail.com \\ DOI : https://doi.org/10.35451/jkg.v2i2.418
}

\begin{abstract}
Complaints of respiratory disorders are a sign of a disease that attacks the respiratory system that can occur for everyone. One of the factors that can affect someone experiencing complaints of respiratory distress is the length of time someone is exposed to a substance or objects in the work environment. Scavengers are one of the workers who are directly exposed to dangerous odors or gases that can cause complaints of respiratory problems. This study aims to determine the relationship of work duration with complaints of respiratory disorders in scavengers in Sei Giling Landfill in Tebing Tinggi City. This type of research is quantitative research with an analytic survey approach, using a cross sectional research design. This study uses a total sampling technique of 50 scavengers. Analysis of the data used is the Chi Square test. The results showed that there was a relationship between length of work ( $p$ value $=0.003$ ) with complaints of respiratory disorders. Expected to scavengers to reduce exposure time at landfill and use personal protective equipment while in landfill.
\end{abstract}

Keywords: length of work, respiratory disorders, scavengers 


\section{Pendahuluan}

Infeksi saluran pernapasan akut atau sering di sebut dengan Ispa adalah suatu gangguan penyakit yang menyerang sistem pernapasan atas atau bawah seseorang akibat adanya agen virus, bakteri yang masuk kedalam tubuh seseorang. Dalam perjalanan penyakit mungkin gejala-gejala menjadi lebih berat dan bila semakin berat dapat menyebabkan kegagalan pernafasan dan mungkin meninggal. Biasanya keluhan pernapasan dapat berupa: batuk, keluar dahak, batuk berdahak, nafas yang mengeluarkan bunyi/mengi, merasa sesak nafas, disertai sesak nafas, sakit pada dada, flu dan batuk dengan disertai flu. Masa kerja yang cukup lama dapat memungkinkan akumulasi bahan pencemar dalam paruparu juga akan meningkat, karena telah lama menghirup udara yang terkontaminasi yang merupakan ciri khas pada keluhan gangguan pernapasan. Karakteristik individu yang juga merupakan salah satu faktor terjadinya keluhan gangguan pernapasan yaitu lama kerja dan masa kerja yang paparan setiap harinya dilingkungan pekerjaan, terlebih di tempat yang memiliki bahan berbahaya seperti pencemaran udara yang dapat menyebabkan keluhan pernapasan.

Menurut Kementerian Kesehatan tahun 2018, provinsi dengan penderita ISPA tertinggi di Nusa Tenggara Timur (NTT) sebesar 13,1 persen (Kemenkes, 2018).

Dinkes kota Medan pada pasien rawat jalan di puskesmas Medan tahun 2012-2016 adalah tahun 2012 Ispa mencapai 47,5\%, tahun 2013 ispa menyumbang sebesar $38,4 \%$, ditahun
2014 ispa memyumbang $46,1 \%$, tahun 2015 ispa sebesar 38,87\% dan ditahun 2016 ispa mencapai 40,23\% (Profil Dinas Kesehatan Kota Medan 2016).

Berdasarkan hasil data yang diperoleh dari Dinas Kesehatan Tebing Tinggi ispa menjadi pringkat pertama dari 10 penyakit terbesar yaitu 22.631 ditahun 2017, sedangkan dari data dari puskesmas satria kota tebing tinggi ispa juga menjadi peringkat pertama yaitu sebesar 561 kasus yang dipantau dari bulan september-desember tahun 2017 (Dinas Kesehatan Tebing Tinggi,2017).

Pemulung dengan masa kerja dan tinggal di TPA Jatibarang $\geq$ 3tahun mengalami gangguan keluhan pernapasan sebesar $\quad(88,2 \%)$ (sianipar,2015).

Hasil wawancara yang dilakukan kepada pemulung, ditemukan dari 30 responden terdapat 18 orang mengalami keluhan gangguan pernapasan seperti batuk pilek, sakit tenggorokan yang merupakan tanda dan gelaja dari keluhan gangguan pernapasan saat bekerja, selain itu dari hasil pengamatan bahwa pemulung hampir keseluruhan berada di tpa \pm 9 jam/hari tertapar gas yang berbahaya. Dengan demikian peneliti tertarik untuk melakukan penelitian tentang hubungan lama kerja dengan keluhan gangguan pernapasan pada pemulung di Sei Giling Kota Tebing Tinggi.

\section{METODE PENELITIAN}

Jenis penelitian yang digunakan yaitu penelitian kuantitatif dengan pendekatan survey analitik, menggunakan desain penelitian cross sectional. Populasi dalam penelitian ini yaitu 50 orang pemulung yang bekerja 
di TPA sei giling tebing tinggi dengan menggunakan total sampling. Pengumpulan data pada penelitian ini dengan menggunakan data primer dan data sekunder. Primer dengan wawancara secara langsung kepada responden dengan berpedoman pada kuesioner, sedangkan data sekunder diperoleh dari data Dinas kesehatan kota Tebing Tinggi, Puskesmas Satria tebing tinggi dan dinas kebersihan dan Pertamanan Kota. Data Kemudian diolah dengan menggunakan uji chi square dengan tingkat kepercayaan 95\% (alpha $=5 \%$ ). pengambilan keputusan dengan ketentuan jika nilai $\mathrm{p}<\mathrm{a}$ maka Ho ditolak yang sehingga dapat disimpulkan bahwa terdapat hubungan antara variabel independent dengan dependent.

\section{HASIL}

Tabel 1. Distribusi umur, dan jenis kelamin responden

\begin{tabular}{lcc}
\hline $\begin{array}{l}\text { Karakteristik } \\
\text { Pemulung }\end{array}$ & $(\mathbf{n = 5 0 )}$ & $\begin{array}{c}\text { Persentase } \\
(\mathbf{\%})\end{array}$ \\
\hline Umur & & \\
Pemulung & & \\
$<30$ tahun & 18 & 36 \\
$\geq 30$ tahun & 32 & 64 \\
\hline Jenis Kelamin & & \\
Laki-laki & 17 & 34 \\
Perempuan & 33 & 66
\end{tabular}

Tabel 1 menjelaskan bahwa
berdasarkan hasil analisis umur diperoleh umur $\geq 30$ tahun sebanyak 32 responden $(64 \%)$, sedangkan jenis kelamin lebih banyak pada perempuan sebesar 33 responden (66\%).

Tabel 2. Distribusi Responden Berdasarakan Lama kerja di TPA Sei Giling Tebing Tinggi

\begin{tabular}{clcc}
\hline No & Karakteristik & $\mathbf{f}$ & $\%$ \\
\hline 1 & $\begin{array}{l}\text { Lama Kerja } \\
<8 \text { Jam/hari }\end{array}$ & 25 & 100,0 \\
\hline
\end{tabular}

\begin{tabular}{rccc}
\hline & $\geq 9$ jam/hari & 25 & \\
\hline & Total & $\mathbf{5 0}$ & $\mathbf{1 0 0 , 0}$ \\
\hline 2 & $\begin{array}{l}\text { Masa Kerja } \\
<3 \text { tahun } \\
\geq 4 \text { tahun }\end{array}$ & 18 & 100,0 \\
& 32 & \\
\hline & Total & $\mathbf{5 0}$ & $\mathbf{1 0 0 , 0}$ \\
\hline
\end{tabular}

Berdasarkan tabel 2 didapatkan bahwa 30 responden yang bekerja $\geq 9$ jam/hari dengan masa kerja $\geq 4$ tahun.

Tabel 3. Distribusi Responden Berdasarakan keluhan gangguan pernapasan di TPA Sei Giling Tebing Tinggi

\begin{tabular}{lll}
\hline $\begin{array}{l}\text { Keluhan } \\
\text { gangguan } \\
\text { pernapasan }\end{array}$ & $\mathbf{f}$ & $\mathbf{\%}$ \\
Ya & & \\
Tidak & 33 & 66.0 \\
\hline Total & 17 & 34.0 \\
\hline
\end{tabular}

Dari tabel 3 dapat diketahui bahwa pemulung yang mengalami keluhan gangguan pernapasan (66.0\%) lebih banyak daripada pemulung yang tidak mengalami keluhan gangguan pernapasan (34.0\%). Pemulung di TPA sei giling ternyata ada yang tidak merasakan keluhan gangguan pernapasan sama sekali (17 orang).

Tabel 4. Hubungan Lama kerja Dengan keluhan gangguan pernapasan pemulung di TPA Sri Giling Tebing Tinggi

\begin{tabular}{|c|c|c|c|c|}
\hline \multicolumn{4}{|c|}{ Keluhan gangguan pernapasan } & \multirow{2}{*}{$\begin{array}{c}p- \\
\text { Valu } \\
e \\
\end{array}$} \\
\hline \multirow{2}{*}{$\begin{array}{l}\text { Lama } \\
\text { kerja }\end{array}$} & $\begin{array}{c}\text { Ada } \\
\text { keluhan }\end{array}$ & $\begin{array}{c}\text { Tidak } \\
\text { keluhan }\end{array}$ & Total & \\
\hline & $\mathrm{n} \quad \%$ & $\mathrm{n} \quad \%$ & $\%$ & \\
\hline
\end{tabular}




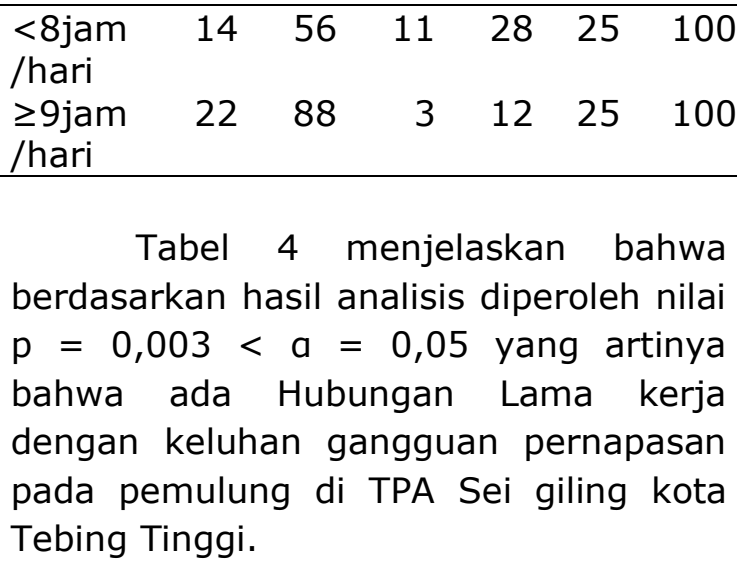

\section{PEMBAHASAN}

Berdasarkan hasil yang peneliti yang didapat diketahui bahwa Lama kerja pemulung di tpa tebing tinggi $\geq 9$ jam/hari sebanyak 25 orang pemulung (50\%) sedangkan masa kerja pemulung $\geq 4$ tahun sebanyak 32 orang pemulung (64\%) (Tabel 2). Lamanya para pemulung di TPA adalah untuk mencari bahan sisa sayuran atau benda yang bisa dijual kembali untuk mendapatkan nilai tambahan rupiah.

Tabel 3 menunjukkan bahwa distribusi frekuensi dan persentase responden diketahui bahwa sebanyak 33 orang pemulung $(66 \%)$ yang mengalami keluhan gangguan pernapasan, sedangkan yang tidak mengalami keluhan gangguan pernapasan ada 17 orang pemulung (34\%).

Berdasarkan hasil uji statistic dengan menggunakan uji Chi Square menunjukkan bahwa p.value $(0,003)$ dengan $\leq a(0,05)$, yang berarti ada hubungan lama kerja dengan keluhan gangguan pernapasan pada pemulung di TPA Sei Giling Kota Tebing tinggi (Tabel $4)$.

Selain itu responden dengan durasi kerja $>8$ jam/hari sebanyak 61 $(81,3 \%)$, sedangkan responden dengan durasi kerja $\leq 8$ jam/hari sejumlah 14 orang $(18,7 \%)$. Responden yang 0,00 ตुemilik masa kerja $>5$ tahun sejumlah 57 orang $(76 \%)$, sedangkan responden yang memiliki masa kerja $\leq 5$ tahun sebanyak 18 orang (24\%) (putri, 2017). Sedangkan penelitian yang dilakukan oleh hartini dan kumalasari menyatakan bahwa pemulung dengan masa kerja dan tinggal di TPA Jatibarang $\geq 3$ tahun mengalami gangguan keluhan pernapasan sebesar $(88,2 \%)$. Hal ini dikarenakan semakin lama seseorang bekerja, maka semakin banyak terapapar zat berbahaya ke dalam tubuh oleh lingkungan kerja yang tidak sehat. Masa kerja > 5 tahun lebih banyak mengalami keluhan pernapasan ringan sebanyak $68,2 \%$ dan pernapasan berat sebanyak $31,8 \%$ (Hartini dan kumalasari, 2015)

Menurut Kementrian Tenaga Kerja (2004) menyatakan bahwa jumlah jam kerja standar adalah delapan jam kerja dalam lima hari atau 40 jam dalam seminggu. Hal ini menunjukkan bahwa rata- rata pemulung bekerja melebihi jam kerja standar yang ditetapkan oleh Kementerian Tenaga Kerja (Kementrian Tenaga kerja, 2004)

\section{KESIMPULAN}

Berdasarkan hasil penelitian dapat disimpulkan bahwa :

1. Lama kerja pemulung $\geq 9$ jam/hari (50\%)

2. Sebagain besar pemulung mengalamin Keluhan gangguan pernapasan

3. Terdapat hubungan yang signifikan antara lama kerja dengan keluhan gangguan pernapasan pada pemulung di tpa sei giling kota tebing tinggi.

\section{DAFTAR PUSTAKA}


Dinas Kesehatan Kota Tebing Tinggi. (2016). Profil Kesehatan Kota Tebing : Program Pengendalian ISPA, Pengendalian Penduduk dan Keluarga Berencana Kota Tinggi Tinggi tahun 2018. Diakses dari http://www.depkes.go.id/resource s/download/profil/PROFIL_KAB_KO TA_2018/1274_Sumut_Kota_Tebin g_Tinggi_2018.pdf

Hartini, E., \& Kumalasari, R. J (2015). Faktor risiko paparan gas Amonia dan Hidrogen Sulfida terhadap keluhan gangguan kesehatan pada pemulung di TPA Jatibarang Kota Semarang. Jurnal Kesehatan Masyarakat, 14 (1), 1-10

Keputusan Menteri Tenaga Kerja dan Transmigrasi Nomor KEP. 102/MEN/VI/2004 tentang Waktu Kerja Lembur dan Upah Kerja Lembur. Diakses dari https://www.bpjsketenagakerjaan. go.id/assets/uploads/peraturan/09 012015_112153_Permen_No.19_T h.2012.pdf

Putri, R. T., Joko, T., \& Dangiran, H. L (2017). Hubungan karakteristik pemulung dan penggunaan alat pelindung pernapasan dengan keluhan gangguan pernapasan pada pemulung di TPA Jatibarang, Semarang. Jurnal Kesehatan Masyarakat, 5(5), 838-849.

Profil Dinas Kesehatan Provinsi Sumatera Utara. (2016). Dinas Kesehatan Provinsi Sumatera Utara. Diakses dari http:// dinkes.sumutprov.go.id/v2/downlo ad.html
Sianipar, R. H. (2009). Analisis risiko paparan Hidrogen Sulfida pada masyarakat sekitar TPA sampah Terjun Kecamatan Medan Marelan Tahun 20015 (Tesis, Universitas Sumatera Utara). Diakses dari http://library.usu.acc.id//downlo $\mathrm{ad} / \mathrm{fkm} / \mathrm{fkm}$-sianiparpdf 